\title{
PEMBINAAN OLIMPIADE MATEMATIKA KELAS VA CI SD NEGERI UNGARAN I YOGYAKARTA
}

\author{
Padrul Jana ${ }^{\# 1}$ \\ \#Pendidikan Matematika, Universitas PGRI Yogyakarta \\ Jl Raya PGRI 1, Bantul, Yogyakarta \\ 1padrul.jana@upy.ac.id
}

\begin{abstract}
ABSTRAK
Pembinaan olimpiade matematika pada Sekolah dasar Negeri Ungaran I Yogyakarta diperlukan karena beberapa hal yaitu, tersedianya bibit unggul sehingga rugi kalau tidak dibina dan dibimbing serta selama ini proses pembinaan belum rutin atau menjelang ada lomba saja. Fakta tersebut menginisiasi pengabdi untuk melakukan kegiatan pembinaan olimpiade matematika di sekolah tersebut. Tahapan yang dilalui adalah pemberian pre test, treatment, dan post test sedangkan metode yang digunakan dalam kegiatan pembinaan ini adalah ceramah, diskusi, dan presentasi. Hasil yang dicapai adalah terlaksananya pembinaan olimpiade dan meningkatkan nilai rata-rata skor pre test dan post test sebesar 21,37. Meningkatnya skor tersebut menjadi salah satu indikator telah meningkatnya pemahaman siswa dalam mengerjakan soal-soal olimpiade, harapannya dapat mempersiapkan calon juara olimpiade matematika sejak dini.
\end{abstract}

Keywords - Matematika, Olimpiade, Sekolah Dasar.

\section{PENDAHULUAN}

Ilmu pengetahuan dan teknologi berperan penting terhadap perubahan dan kemajuan suatu bangsa termasuk bangsa Indonesia. Untuk kemajuan Indonesia diperlukan adanya generasi muda yang kompeten dalam penguasaan ilmu pengetahuan dan teknologi. Pemberian pemahaman tentang basic science merupakan salah satu upaya untuk menciptakan generasi muda yang berkualitas, edukatif, kompetitif, dan sportif agar mampu bersaing dengan negara lain dalam berbagai bidang kehidupan. Basic science merupakan kumpulan pengetahuan tentang konsep-konsep dasar dalam bidang ilmu pengetahuan alam dan teknologi, misalnya Fisika, Biologi, Kimia, dan Matematika. Mata pelajaran matematika merupakan mata pelajaran wajib, baik di sekolah dasar ataupun sekolah menengah. Mempelajari matematika menjadi penting karena aplikasi matematika sangat erat kaitannya dalam kehidupan sehari-hari serta matematika juga mampu mengembangkan kesadaran tentang nilai-nilai yang esensial[1].

Matematika sebagai salah satu ilmu pengetahuan dasar atau basic science berperan dalam meningkatkan kemampuan generasi penerus bangsa melalui pengembangan pola pikir dan daya nalar. Salah satu untuk mengembangkan pola pikir dan daya nalar tersebut dapat berupa sebuah lomba atau olimpiade. Bagi para siswa yang mulai menyukai matematika, mereka diberikan kesempatan untuk mengikuti berbagai event kompetisi baik yang diselenggarakan di tingkat kota, wilayah, sampai nasional. Kegiatan ini bertujuan untuk menjajal kemampuan para siswa selain tentunya untuk mencari bibit unggul untuk dipilih menjadi duta pada jenjang kompetisi yang lebih tinggi. Salah satu event yang diharapkan dapat memberikan motivasi bagi para siswa penggemar matematika dan sains adalah diselenggarakannya program Olimpiade Sains Nasional (OSN) [2].

Sekolah Dasar Negeri Ungaran memiliki kelas Cerdas Istimewa, siswanya merupakan hasil seleksi diantaranya seleksi tingkat Intelligence Quotient (IQ). Sumber daya yang ada di SDN Ungaran sangat disayangkan kalau tidak dimanfaatkan dalam event lomba maupun olimpiade matematika akibat minimnya pembinaan dan bimbingan olimpiade. Merespon 
fakta tersebut dalam rangka menyiapkan peserta yang unggul dalam ajang olimpiade matematika, perlu pembinaan dan bimbingan yang masif dan matang. Pola bimbingan, pembinaan yang baik dan terarah diharapkan akan menghasilkan peserta yang unggul dan tangguh baik dari sisi materi olimpiade maupun mental bertanding.

Oleh karena itu, dirasa sangat perlu pembinaan olimpiade matematika kelas VA CI SDN Ungaran I Yogyakarta. Dalam rangka mempersiapkan bibit-bibit unggul yang ada pada SDN Ungaran I khususnya kelas VA CI untuk menghadapi event lomba matematika maupun olimpiade matematika. Tujuan dari kegiatan pembinaan ini adalah mempersiapkan bibit unggul yang ada di SDN Ungaran I dalam menghadapi event lomba matematika maupun olimpiade matematika dan Memberikan pemahaman pada siswa bahwa matematika mudah, menyenangkan dan bermanfaat. Manfaat dari kegiatan pembinaan ini adalah memberi wawasan karakteristik soal-soal olimpiade pada siswa kelas VA CI SDN Ungaran I Yogyakarta dan memberikan motivasi dan penguatan mental saat melaksanakan lomba maupun olimpiade.

\section{TARGET DAN LUARAN}

Target secara umum pada kegiatan pengabdian ini adalah Sekolah Dasar Negeri Ungaran I sedangkan secara spesifik adalah siswa kelas VA CI. Hasil yang diharapkan dalam kegiatan ini adalah siswa memahami materi dan karakteristik soal-soal olimpiade matematika secara komprehensif, sehingga siswa memiliki kesiapan baik secara materi soal maupun mental dalam bertanding untuk menghadapi event lomba matematika maupun olimpiade matematika.

\section{METODE PELAKSANAAN}

Tahapan pelaksanaan kegiatan pengabdian kepada masyarakat ini ada tiga tahap meliputi: pre test, treatment, dan post test. Bentuk kegiatan pre test dilakukan dengan pemberian soal di awal untuk mengetahui kemampuan siswa secara umum dan digunakan sebagai pijakan pemberian treatment yang sesuai dengan kondisi siswa. Treatment yang diberikan kepada siswa berupa pemberian materi dan latihan soal-soal olimpiade. Terakhir adalah post test adalah pemberian soal tes untuk mengukur kemampuan siswa dalam mengerjakan soal-soal olimpiade setelah diberikan treatment. Gambar di bawah ini merupakan alur dari metode pelaksanaan kegiatan pengabdian kepada masyarakat yang dilakukan:

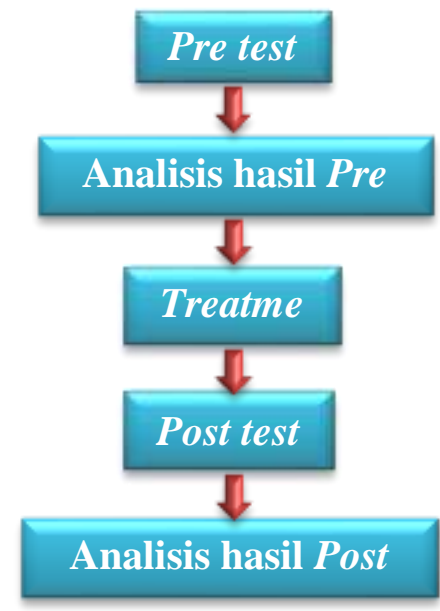

Gambar 1. Alur pelaksanaan pengabdian kepada masyarakat

Metode pelaksaan pada kegiatan pengabdian kepada masyarakat ini menggunakan metode ceramah, diskusi, presentasi. Metode ceramah digunakan ketika pengabdi memberikan materi mengenai konsep-konsep dasar matematika, memotivasi semangat siswa dan karakteristik soal-soal olimpiade siswa. Diskusi diterapkan saat siswa telah mendapat materi, kemudian diberikan soal yang sifatnya eksplorasi dan pengembangan. Presentasi dilakukan untuk mengukur kemampuan siswa dalam memecahkan masalah dan mengeksplorasi soal olimpiade tersebut.

\section{HASIL DAN LUARAN YANG DICAPAI}

Kegiatan pembinaan olimpiade ini diikuti 22 anak yang semuanya berasal dari kelas VA CI selama lima kali pertemuan. Pada pertemuan pertama perkenalan, pendekatan, motivasi dan apersepsi kepada siswa yang berkaitan dengan kegiatan pembinaan. Selain perkenalan pada pertemuan pertama adalah pemberian soal pre test untuk mengetahui kemampuan awal siswa. Hasil pre test pada pertemuan pertama disajikan dalam tabel 
TABEL I

HASIL PRE TEST

\begin{tabular}{cccc}
\hline Skor & Rata-rata & $\begin{array}{c}\text { Std. } \\
\text { Deviasi }\end{array}$ & N \\
\hline Pre test & 49,77 & 12,954 & 22 \\
\hline
\end{tabular}

Hasil pre test menunjukan bahwa rata-rata skor tes adalah 49,77 reratanya masih rendah, setelah melalui analisis hasil pekerjaan siswa memperlihatkan bahwa soal eksplorasi dan soal uraian singkat berbahasa Inggris masih banyak terdapat kesalahan. Merujuk pada hasil pre test dan analisis awal, pembinaan ini menitik beratkan pada soal dengan karakteristik ekspolorasi dan uraian singkat berbahasa Inggris tanpa mengesampingkan soal uraian singkat berbahasa Indonesia. Materi yang digunakan adalah materi matematika SD kelas 4, 5, dan 6 lengkap dengan pengembangannya.

Pertemuan kedua, ketiga, dan keempat adalah penyampaian materi dan pembahasannya. Materi terbagi menjadi menjadi soal isian singkat (berbahasa Inggris dan Indonesia) dan uraian eksplorasi dan pengembangan. Materi tersebut diambil dari kelas 4, 5, dan 6. Metode pada penyampaian materi dilakukan dengan metode ceramah, pengabdi menjelaskan konsep-konsep dasar matematika, karakteristik soal, dan memberikan gambaran umum mengenai soalsoal olimpiade. Selanjutnya, pemberian soal latihan sesuai dengan materi yang disampaikan pada tiap pertemuannya. Latihan soal menggunakan metode diskusi karena sifatnya memecahkan masalah, dengan diskusi harapannya ada tambahan ide dari siswa lain dalam menyelesaikan soal tersebut serta menambah pemahaman siswa. Pada akhirnya, perwakilan siswa menyampaikan hasil diskusi bersama temannya dan memungkinkan sesi tanya jawab antar siswa. Temuan unik pada sesi ini adalah saat siswa menyampaikan hasil diskusinya ternyata ditemukan banyak cara penyelesaian untuk satu soal yang sama dan semua jawabannya benar, sehingga siswa mendapat tambahan alternatif dalam menyelesaikan soal. Berikut adalah beberapa foto dalam pelaksanaan kegiatan pengabdian kepada masyarakat.
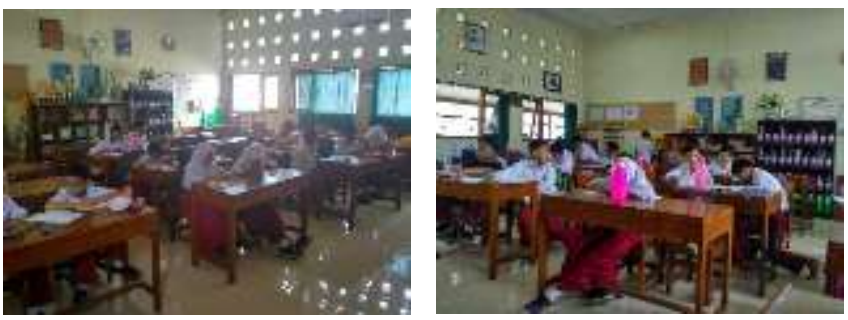

Gambar 2. Pelaksanaan pengabdian kepada masyarakat

Pertemuan kelima adalah pemberian soal post test untuk mengetahui kemajuan selama pembinaan. Soal yang diberikan saat post test berbeda dengan pre test hanya saja memiliki tipe yang sama. Hasil post test disajikan dalam tabel berikut.

TABEL II

HASIL POST TEST

\begin{tabular}{cccc}
\hline Skor & Rata-rata & $\begin{array}{c}\text { Std. } \\
\text { Deviasi }\end{array}$ & N \\
\hline Post test & 71,14 & 11,226 & 22
\end{tabular}

Hasil post test menunjukan kenaikan rata-rata skor dari 49,77 menjadi 71,14. Selisih kenaikan skor tertinggi adalah 40 dan terendah adalah 4 sedangkan selisih rata-rata pre test dan post test adalah 21,37.

\section{KESIMPULAN DAN SARAN}

Berdasarkan kegiatan yang telah dilakukan, hasil yang telah dicapai pada pengabdian masyarakat ini adalah terlaksananya pembinaan dan bimbingan untuk siswa kelas VA CI di SDN Ungaran I Yogyakarta. Hasil pembinaan tersebut telah meningkatkan skor dari hasil pre test ke post test, rata-rata skor meningkat sebesar 21,37. Peningkatan skor tersebut menjadi indikator bahwa pelaksanaan kegiatan pengabdian masyarakat ini dapat meningkatkan wawasan siswa dalam menyelesaikan soal-soal olimpiade. Harapannya dengan meningkatnya pemahaman siswa menjadi dasar untuk persiapan dalam menghadapi lomba matematika ataupun olimpiade matematika.

Adapun saran yang dapat diberikan berdasarkan hasil kegiatan pengabdian ini adalah hendaknya pihak sekolah melanjutkan program pembinaan olimpiade matematika secara rutin. Pembinaan ini terbukti telah meningkatkan 
pemahaman siswa, sehingga ketika ada lomba atau olimpiade sudah disiapkan jauh hari. Lebih dini dalam persiapan dan pembinaan akan dapat memaksimalkan potensi siswa yang ada.

\section{UCAPAN TERIMA KASIH}

Pengabdi mengucapkan banyak terima kasih kepada Sekolah Dasar Negeri Ungaran I Yogyakarta yang telah memberikan kesempatan untuk mengabdi dan bekerja sama sehingga terlaksananya kegiatan ini. Kepada Universitas PGRI Yogyakarta melalui LPPM, penulis mengucapkan banyak terimakasih atas bantuan fasilitas dan perijinan tanpa sumbangsih pihak Universitas PGRI Yogyakarta tentu pengabdi akan mengalami berbagai hambatan dalam pelaksanaannya.

\section{DAFTAR PUSTAKA}

Siagian, "Pengaruh Minat dan Kebiasaan Belajar Siswa Terhadap Prestasi Belajar Matematika," J. Form., vol. Vol 2, no. 20, pp. 122-131, 2012.

A. Trisnowali, "Profil Disposisi Matematis Siswa Pemenang Olimpiade pada Tingkat Provinsi Sulawesi Selatan," J. EST, vol. 1, no. 3, pp. 47-57, 2015. 